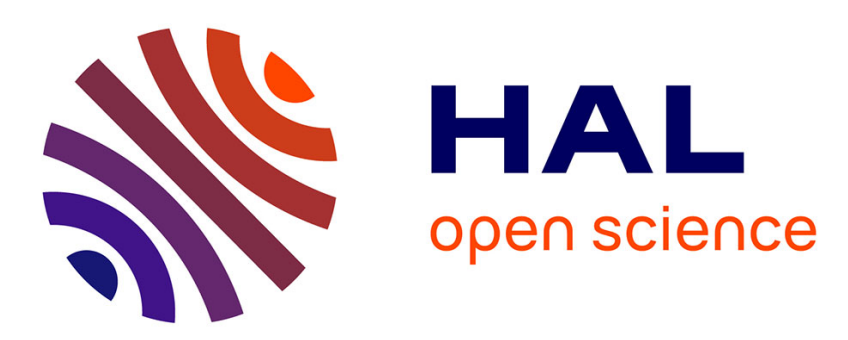

\title{
Infective endocarditis after device closure of atrial septal defects: Case report and review of the literature
}

\author{
Pascal Amedro, Camille Soulatges, Alain Fraisse
}

\section{To cite this version:}

Pascal Amedro, Camille Soulatges, Alain Fraisse. Infective endocarditis after device closure of atrial septal defects: Case report and review of the literature. Catheterization and Cardiovascular Interventions, 2017, 89 (2), pp.324 - 334. 10.1002/ccd.26784 . hal-01823067

\section{HAL Id: hal-01823067 \\ https://hal.umontpellier.fr/hal-01823067}

Submitted on 11 Dec 2019

HAL is a multi-disciplinary open access archive for the deposit and dissemination of scientific research documents, whether they are published or not. The documents may come from teaching and research institutions in France or abroad, or from public or private research centers.
L'archive ouverte pluridisciplinaire HAL, est destinée au dépôt et à la diffusion de documents scientifiques de niveau recherche, publiés ou non, émanant des établissements d'enseignement et de recherche français ou étrangers, des laboratoires publics ou privés. 


\title{
Infective Endocarditis After Device Closure of Atrial Septal Defects: Case Report and Review of the Literature
}

\author{
Pascal Amedro, ${ }^{1,2 *} \mathrm{MD}, \mathrm{PhD}$, Camille Soulatges, ${ }^{1} \mathrm{MD}$, and Alain Fraisse, ${ }^{3} \mathrm{MD}, \mathrm{PhD}$
}

\begin{abstract}
We report a case of late infective endocarditis in an 8-year-old boy 3 years after transcatheter closure of an atrial septal defect with the Amplatzer Atrial Septal Occluder Device. Echocardiography showed a very thick pannus lining the left atrial disc of the prosthesis, with some mobile elements. MRI showed several cerebral microemboli. The patient had dental caries and blood cultures found Staphylococcus aureus. Patient was treated with gentamicin and oxacillin before surgical removal of the prosthesis. Twenty-one cases of infective endocarditis after atrial defect device closure have been reported in the literature (13 ostium secundum ASD and 8 patent foramen ovale). Seven pediatric cases were reported. $S$. aureus was the most frequent bacterium. Antibiotics were administered in all cases and most patients $(n=18)$ underwent surgical removal of the device. Incomplete endothelialization of the prosthesis was a suggested mechanism. Two patients died after surgery.
\end{abstract}

Key words: Amplatzer Atrial Septal Occluder Device; ASD; atrial septal defect; infective endocarditis; pediatrics

\section{INTRODUCTION}

Infective endocarditis is a relatively rare complication associated with a significant morbidity and mortality [1]. Its prevention has not decreased its incidence (3-7 per 100,000 person-years) [2-4] probably as a consequence of medical progress [5].

In patients with congenital heart diseases (CHD), medical advances have modified the epidemiology of this population [6,7], considered at risk of developing infective endocarditis $[8,9]$. The incidence of infective endocarditis in adults with CHD has been estimated as between 15 and 140 times that of the general population and represents $0.42-4 \%$ of hospitalizations $[10,11]$.

In recent guidelines, infective endocarditis prevention strategies have restrained antibiotic prophylaxis and reinforced nonspecific hygiene measures $[8,12,13]$. For CHD patients, antibiotic prophylaxis before dental procedure is now recommended in five situations: prosthetic valve, previous infective endocarditis, unrepaired cyanotic CHD (including palliative shunts and conduits), completely repaired congenital heart defect with prosthetic material or device (whether placed using surgery or catheter intervention, during the first 6 months after the procedure), and repaired CHD with residual defects at the site or adjacent to the site of a prosthetic patch or prosthetic device $[8,12]$.

Atrial septal defects (ASD) represent the second most frequent CHD (after ventricular septal defects),

\footnotetext{
${ }^{1}$ Pediatric and Congenital Cardiology Department, M3C Regional Center, University Hospital, Montpellier, France

${ }^{2}$ Physiology and Experimental Biology of Heart and Muscles Laboratory - PHYMEDEXP, UMR CNRS 9214 - INSERM U1046, Montpellier, France

${ }^{3}$ Pediatric Cardiology Service, Royal Brompton and Harefield Hospital Trust, London, United Kingdom
}

*Correspondence to: Pascal Amedro; Pediatric and Congenital Cardiology Department, CHU Arnaud De Villeneuve, 371 avenue du Doyen Gaston Giraud, 34295 Montpellier Cedex 5, France. E-mail: p-amedro@chu-montpellier.fr 


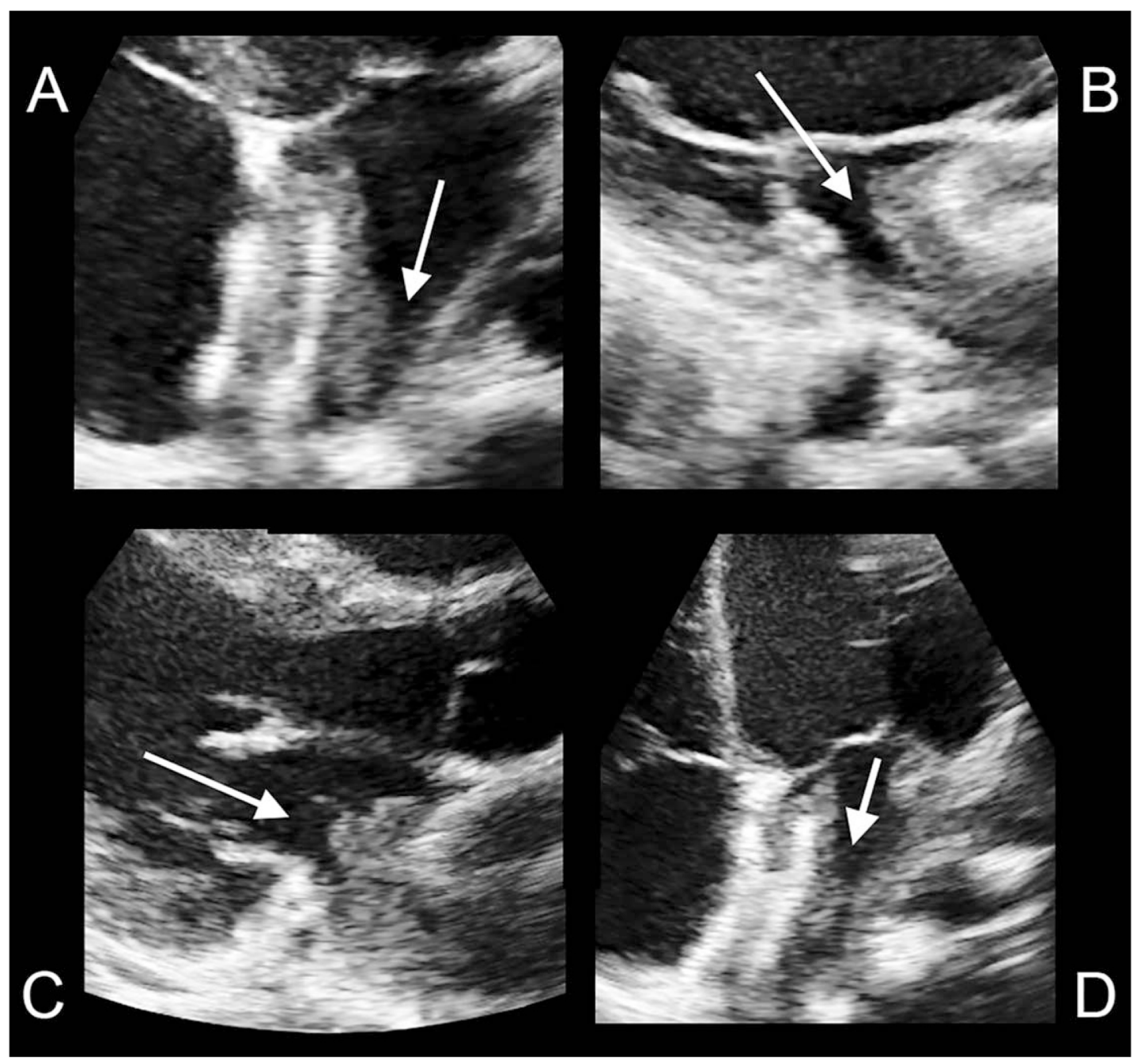

Fig. 1. Transthoracic echocardiographic images. Apical four chamber view shows thick pannus on left side of ASO (arrow, A). Parasternal long-axis view shows hyperechogenic vegetation on left side of ASO (arrows, B and C). Decreasing in size of vegetation after 6 weeks antibiotic treatment (arrow, D).

with a worldwide reported birth prevalence of 2.62 per 1,000 live births [14]. Ostium secundum ASD are predominant $(80 \%)$ and eligible for catheter closure when the left-to-right shunt is significant, depending on the size of atrial septal rims [15]. Patent foramen ovale (PFO) is a small interatrial shunt caused by incomplete apposition of the septum primum to the septum secundum. Catheter closure is usually performed on carefully selected patients, as we need more data from randomized clinical trials comparing oral anticoagulants, antiplatelet therapy, and catheter occlusion $[16,17]$.

Prosthetic infective endocarditis after ASD transcatheter closure is extremely rare, especially beyond the first few months after the procedure. We report one recent pediatric case of late infective endocarditis that occurred in an 8-year-old boy. We also reviewed the literature regarding infective endocarditis after atrial defect device closure.

\section{METHOD}

We searched three electronic databases on April 2016 (PubMed, EMBASE, and Web of Science) by using a combination of the terms "atrial septal defect" and "endocarditis." We also used the terms "catheter device," "device closure," "patent foramen ovale," "PFO," "ASD," “Amplatzer," “ASO," "STARFlex," “CardioSEAL," "infective endocarditis," and "interventional catheterization" in combination. The selection criteria were as follows: follow-up after ASD device closure, catheter devices complications, prosthetic endocarditis, and articles written in English. We did not set any restriction to study 


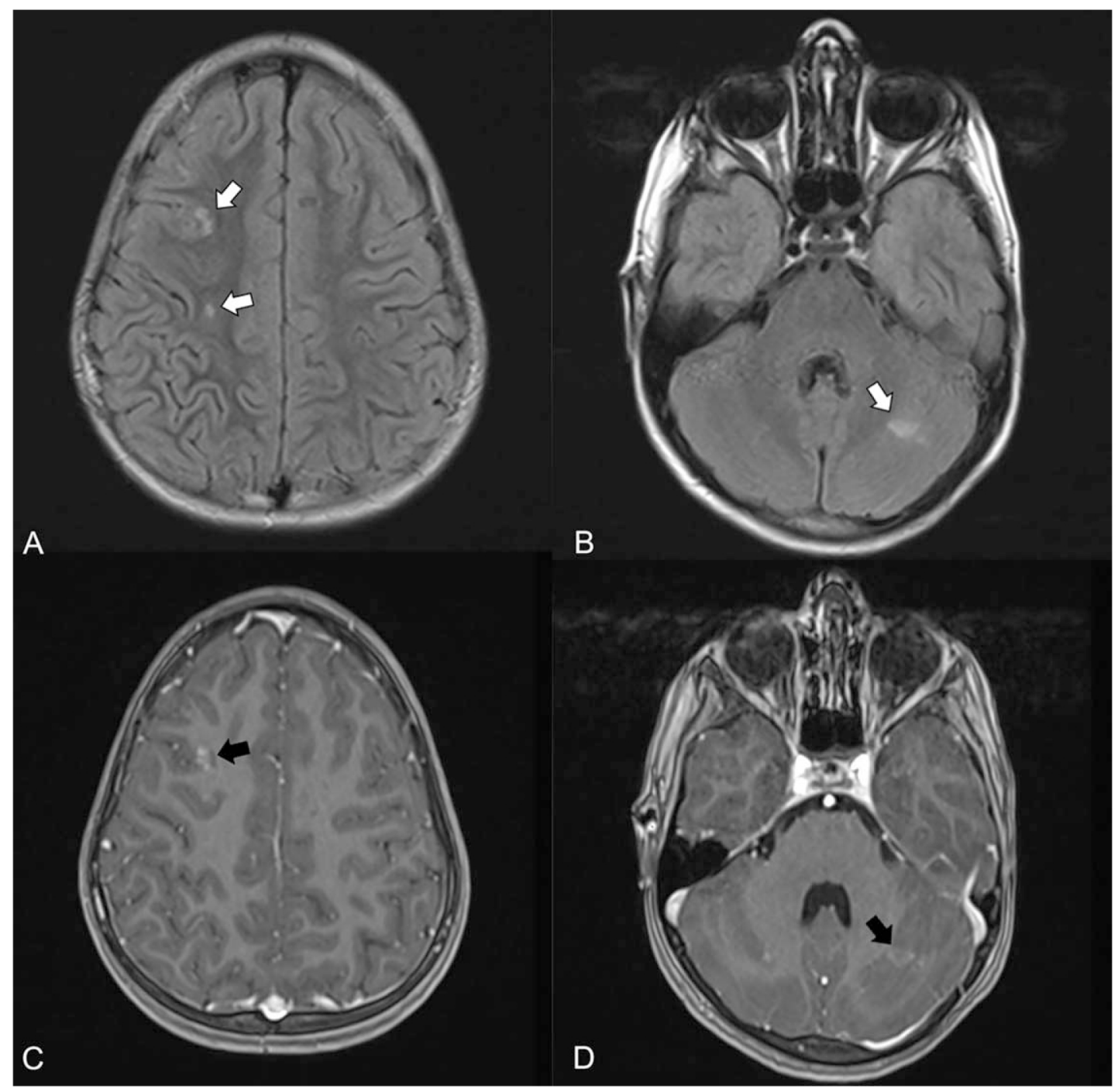

Fig. 2. Brain MRI. Axial-plane Flair T2-wheigted sequences reveal multiple cortico-subcortical lesions in the right frontal area (white arrow, A) and in the left cerebellar hemisphere (white arrow, B), with slight gadolinium enhancement of some lesions in T1-weighted sequences (black arrows, C and D).

setting, era, or locale. Pediatric and adult patients were eligible. In title and abstract screening, two reviewers (P.A. and C.S.) independently reviewed articles identified by the search. Studies identified in title or abstract screening were included for full-text review.

\section{CASE REPORT}

At the age of five, our patient underwent transcatheter closure of ostium secundum ASD with the Amplatzer Atrial Septal Occluder Device (ASO; AGA Medical Corporation, Golden Valley, Minnesota). He was treated with antiplatelet therapy for 6 months postimplant (aspirin $5 \mathrm{mg} / \mathrm{kg} /$ day). Three years later, after a normal annual follow-up, he presented with pro- longed fever, severe weight loss, and typical Janeway lesions on palms and soles. It is worthy noting that he had several untreated dental caries. Echocardiography showed a very thick pannus lining the left atrial disc of the prosthesis, with some mobile elements (Figure 1).

The patient presented no neurological symptoms but an MRI showed several cerebral microemboli (Figure 2). All blood cultures found Oxacillinsusceptible Staphylococcus aureus. The patient underwent intravenous antibiotic treatment with Gentamicin (2 weeks, $3 \mathrm{mg} / \mathrm{kg} /$ day) and Oxacillin (6 weeks, $200 \mathrm{mg} / \mathrm{kg} /$ day). Dental care was performed. Negative blood cultures were rapidly obtained. Echocardiography showed a decrease in the size of the pannus and the disappearance of mobile elements (Figure 1). 


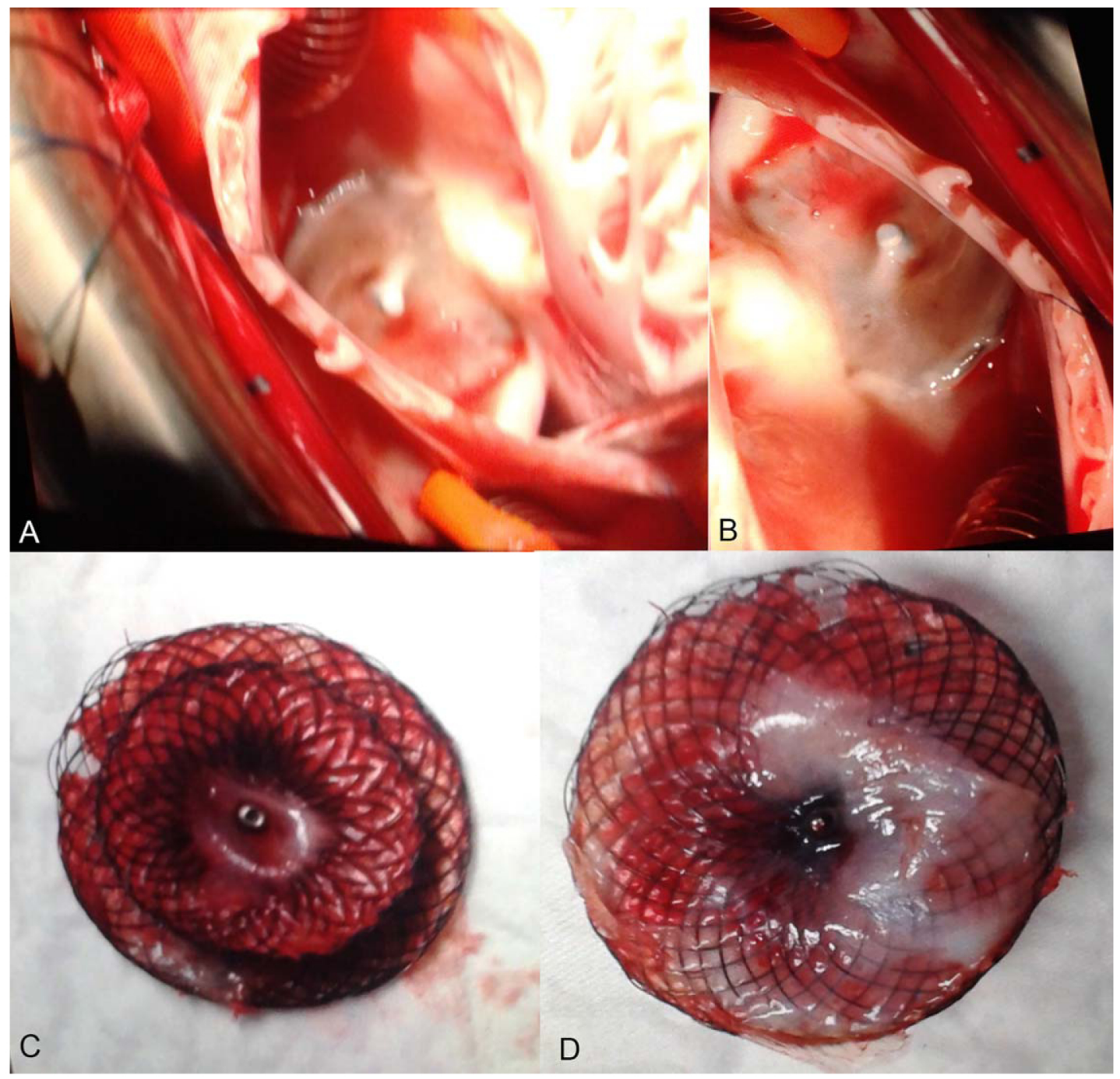

Fig. 3. Intraoperative photograph from right atrium view suggesting limited endothelialization of ASO (A,B). Removed ASO from right (C) and left (D) sides confirming limited endothelialization. [Color figure can be viewed at wileyonlinelibrary.com.]

After the end of medical treatment, a PET scan was performed and showed no activity. Cerebral lesions on the MRI remained stable. No immune deficiency was found. Three months after the end of antibiotic treatment, blood tests remained negative. After analyzing similar cases reported in the literature, we decided to remove the prosthesis surgically. After right atriotomy, under cardiopulmonary bypass and aortic crossclamping, the cardiac surgeon noticed a slightly incomplete endothelialization on the right atrial disc. The prosthesis was carefully removed from the right to the left. The left side was approximately similar to the right but some slight and nonspecific thickening (Figure 3) was clearly present. The surgeon observed no vegetation or any other noticeable lesion and closed the ASD with a pericardial patch. The bacteriological analysis of the prosthesis came back negative. After 2 years of follow-up, the patient's clinical course is favorable, including neurologically.

\section{LITERATURE REVIEW}

We selected seven ASD device follow-up studies [18-24], one meta-analysis of percutaneous and surgical ASD closure [25], and two FDA databases [26,27]. We identified twenty-one cases of infective endocarditis following atrial septal device closure [28-47] (Table I). Three studies did not meet the selection criteria (fungal endocarditis following ventricular septal defect hybrid procedure [48], atrial septal defect presenting with Brucella endocarditis [49], and patch abcess after surgical closure of an atrial septal defect [50]). 


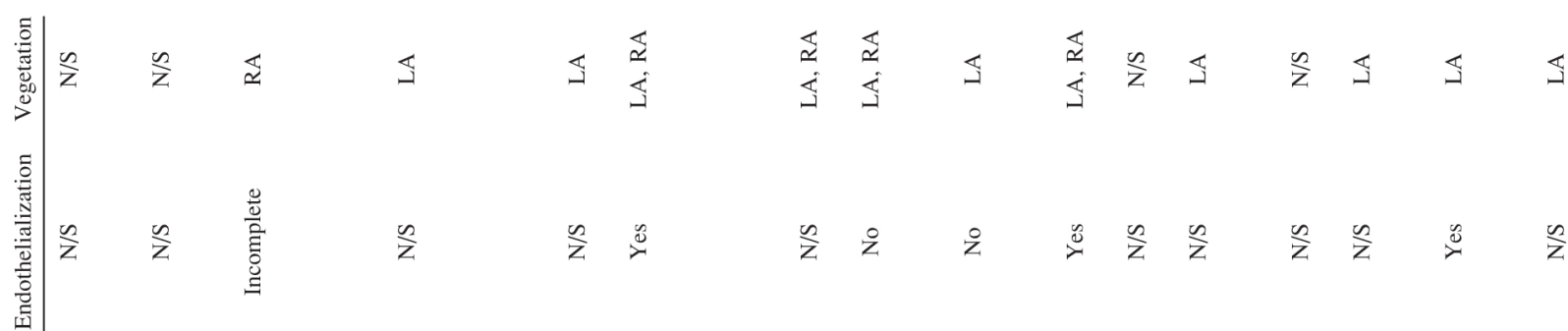

II In

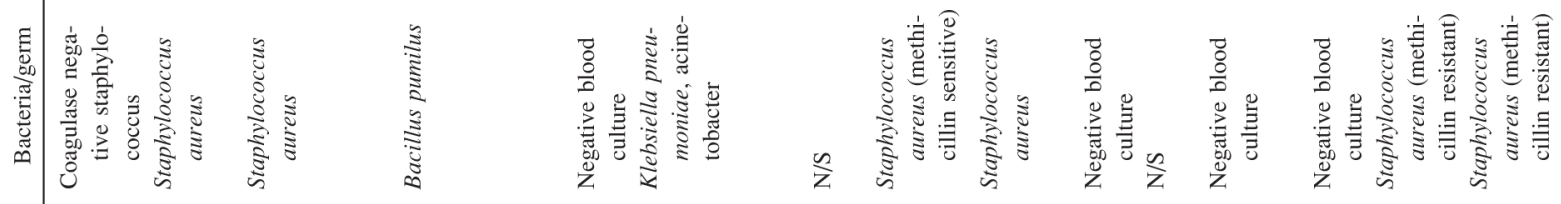

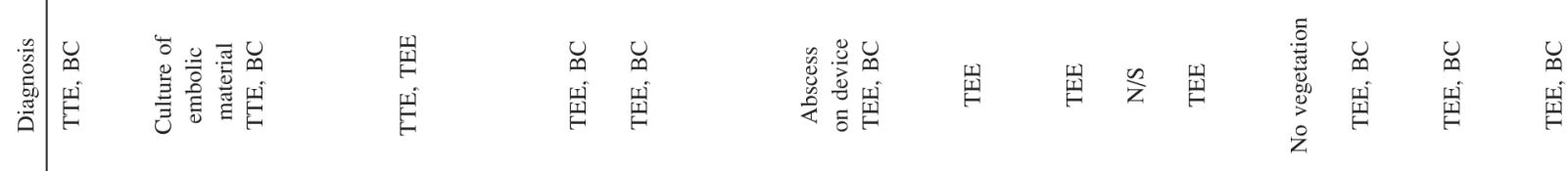

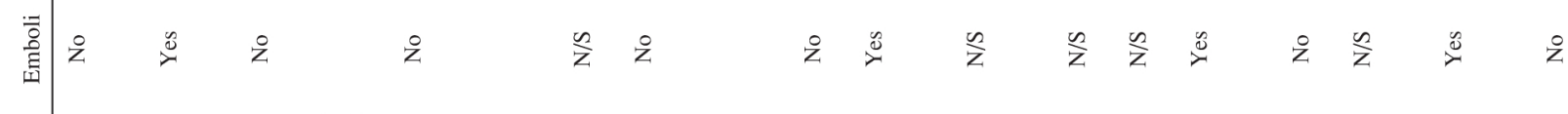

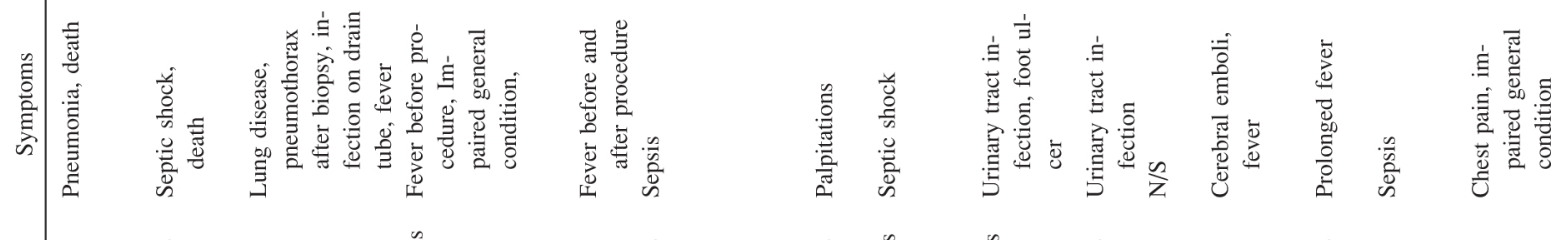

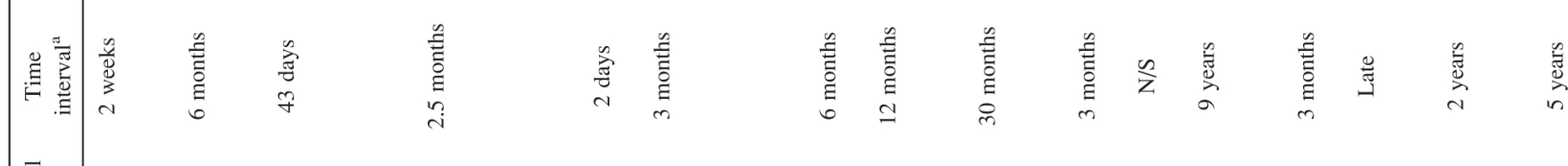
|. 


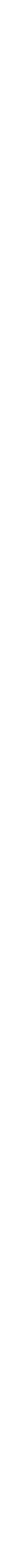




\begin{tabular}{|c|c|c|c|c|c|}
\hline Clinical data & & & & $\mathrm{N}$ & References \\
\hline \multirow[t]{2}{*}{ CHD } & & Ostium secundum ASD & & 13 & {$[28,29,32,34,35,39,40,42-45,47,53]$} \\
\hline & & PFO & & 8 & {$[28,30,31,33,36-38,41]$} \\
\hline \multirow[t]{6}{*}{ Device } & & ASO & & 14 & {$[29,32,34-36,39-45,47,53]$} \\
\hline & & ASDOS & & 2 & {$[28]$} \\
\hline & & CardioSEAL & & 2 & {$[30,37]$} \\
\hline & & STARFlex & & 1 & {$[33]$} \\
\hline & & Cardiastar & & 1 & {$[31]$} \\
\hline & & Helix & & 1 & {$[38]$} \\
\hline \multirow{4}{*}{$\begin{array}{l}\text { Time interval } \\
\text { since procedure }\end{array}$} & & $<6$ months & & 7 & {$[28-32,36,39]$} \\
\hline & & $6-24$ months & & 5 & {$[28,33,34,41,53]$} \\
\hline & & $>24$ months & & 7 & {$[35,38,42-45,47]$} \\
\hline & & Not specified & & 2 & {$[37,40]$} \\
\hline \multirow[t]{25}{*}{ Diagnosis } & Blood culture & Staphylococcus & Aureus & 10 & {$[28,29,34,35,40-42,44,47,53]$} \\
\hline & & & $\begin{array}{r}\text { Coagulase } \\
\text { negative }\end{array}$ & 1 & {$[28]$} \\
\hline & & Bacillus pumilus & & 1 & {$[30]$} \\
\hline & & $\begin{array}{c}\text { Klebsiella pneumonia } \\
\text { and acinetobacter }\end{array}$ & & 1 & {$[32]$} \\
\hline & & Streptococcus & Pyogenes & 1 & {$[43]$} \\
\hline & & & Beta hemolytic & 1 & {$[45]$} \\
\hline & & Negative & & 4 & {$[31,36,38,39]$} \\
\hline & & Not specified & & 2 & {$[33,37]$} \\
\hline & Symptoms & Fever & & 8 & {$[29-31,38,39,42,44,45]$} \\
\hline & & Sepsis & & 5 & {$[28,32,34,40,43]$} \\
\hline & & Urinary tract infection & & 2 & {$[35,36]$} \\
\hline & & Cerebral emboli & & 2 & {$[38,45]$} \\
\hline & & Cutaneous lesions & Cellulitis & 1 & {$[43]$} \\
\hline & & & Foot ulcer & 1 & {$[35]$} \\
\hline & & & Janeway lesions & 1 & {$[44]$} \\
\hline & & Palpitations & & 1 & {$[33]$} \\
\hline & & Pain & Chest pain & 1 & {$[41]$} \\
\hline & & & Muscular pain & 1 & {$[44]$} \\
\hline & & Petechiae & & 1 & {$[47]$} \\
\hline & Echocardiography & TEE & & 13 & {$[30-32,34-36,38,40-42,44,45,47]$} \\
\hline & & TTE & & 5 & {$[28-30,43,53]$} \\
\hline & Vegetation & Left atrium & & 10 & {$[30,31,35,38,40-42,45,47,53]$} \\
\hline & & Right atrium & & 1 & [29] \\
\hline & & Left and right atrium & & 6 & {$[32-34,36,43,44]$} \\
\hline & & Not specified & & 4 & {$[28,37,39]$} \\
\hline \multirow[t]{2}{*}{ Treatment } & & Antibiotics only & & 3 & {$[31,39,40]$} \\
\hline & & Surgical removal of device & & 18 & {$[28-30,32-38,41-45,47,53]$} \\
\hline \multirow[t]{4}{*}{ Endothelialization } & & Absent & & 5 & {$[34,35,44,45,53]$} \\
\hline & & Incomplete & & 3 & {$[29,43,47]$} \\
\hline & & Present & & 3 & {$[32,36,41]$} \\
\hline & & Not specified & & 10 & {$[28,30,31,33,37-40,42]$} \\
\hline
\end{tabular}

Infective endocarditis is commonly considered to be an exceptional event following percutaneous ASD device closure. No cases of endocarditis were reported in seven large series that included a total of 3568 patients who underwent ASD closure with mean follow-up ranging from 2 to 20 years [18-24]. In their review and meta-analysis of 1812 percutaneous versus 1270 surgical ASD closures, Butera et al. [25] only found one case of endocarditis in the "surgery" group. No case of endocarditis were reported in the FDA Maude database (United States Food and Drug Administration manufacturer and user facility device experience) among approximately 12,000 devices from AGA Medical Corporation (Amplatzer) and 8,950 devices from NMT Medical (STARflex, CardioSEAL) [26,27].

Eight cases of infective endocarditis occurred after patent foramen ovale (PFO) percutaneous closure (1 ASDOS, 2 CardioSEAL, 2 ASO, 1 Helex, 1 CardioStar, 1 STARFlex). Twelve cases of ostium secundum ASD were closed with ASO devices (size 22-32 mm, size not specified for 7 patients). Including our pediatric patient, 7 cases of infective endocarditis occurred in 
children, after ostium secundum ASD device closure (mean age at procedure of 5 years). The absence of postprocedure residual shunt was only reported in six patients, but mostly not specified. Mean age when endocarditis occurred in the adult group was 53 years old. Diagnosis was made from 2 days to 12 years after the procedure. Thirteen cases can be considered to be late infective endocarditis ( 6 months or more after procedure). Five patients developed early symptoms following device implantation: 2 days after intervention for one patient (procedure carried out under antibiotics following a recent infection), and 2-3 months after the procedure for 3 patients. In each case, a history of recent infection before the procedure was noted.

Various clinical presentations included persistent fever, impaired general condition, chest pain, cerebral emboli, urinary tract infection, meningitis, petechiae, palpitations, and septic shock. A history of dental carries was never mentioned (besides our pediatric case).

Diagnosis was made by transesophageal echocardiography (TEE) and positive blood cultures in most cases, sometimes by transthoracic echocardiography (TTE) especially in the pediatric cases. Staphylococus aureus was found in most cases. Other reported germs were streptococcus, Bacillus pumilus, and Klebsiella pneumonia. Negative blood cultures occurred in four cases.

Most patients $(n=18)$ underwent surgical removal of the device, usually after at least 2-3 weeks of antibiotics. All the patients received antibiotics for at least 6 weeks. A few patients were treated with antibiotics only. Endothelialization of the device was reported by surgeon as absent or incomplete in 8 cases, complete in 3 cases and not specified in 10 cases. Two adult patients died after surgery [28] (Table II).

\section{DISCUSSION}

Mechanisms of infection after ASD device closure remain unclear. In many of these reported cases, it is difficult to know whether the introduction of bacteria occurred before, during, or after the catheter procedure. However, in some cases, patients with recent infections underwent a catheter procedure [30]. Even if preanesthetic blood tests are negative, we recommend postponing ASD closure when the patient presents with any recent clinical symptoms of infection.

In other reported cases of infective endocarditis, some invasive procedures were performed shortly after catheter occlusion, suggesting bacteremia following skin puncture. The risk for infective endocarditis might have therefore been underestimated [29].

Some authors suggested that infection might have occurred before the end of neo-endothelialization, with seeding of microorganisms after the procedure, and development of thrombus and bacteremia. In animal studies, the neo-endothelium is supposed to completely recover the ASD prosthesis within a few weeks [51]. Therefore, the length of antiplatelet therapy and antibiotic prophylaxis of endocarditis has been arbitrarily recommended for 6 months after ASO implantation [12].

These cases of infective endocarditis might therefore challenge the duration of endocarditis prophylaxis after transcatheter ASD closure. Recent guidelines on prevention, diagnosis, and treatment of infective endocarditis recommend good oral hygiene and regular dental care to reduce the risk of infection $[8,12]$. However, in a recent survey, more than half of the pediatric cardiologists do not follow the American Heart Association 2007 guidelines in their practice [52]. Therefore, counseling for optimal oral health in patients at risk of infective endocarditis needs to be improved in current practice.

\section{LIMITATIONS}

This review is designed as a summary; therefore, no conclusions can be drawn.

\section{CONCLUSION}

Infective endocarditis is considered to be an exceptional event following percutaneous ASD device closure. However, 21 cases had previously been reported in the literature, besides our current pediatric case report. Specific infectious mechanisms remain unclear. Therefore, before ASD closure, recent infectious events should be investigated and, if suspected, catheter procedure should be postponed. As incomplete device endothelialization is impossible to detect in routine follow-up, it may be worth insisting on prevention of infection on a long-term, or even life-long, basis following ASD device closure. Moreover, oral health prevention probably needs to be reinforced.

\section{ACKNOWLEDGMENT}

We thank Doctor Pierre Meyer (Pediatric Neurology Department, University Hospital, Montpellier, France) and Sebastien Mounier (graphic designer) for their contribution to this work. Galien Health Publishing provided medical writing assistance.

\section{REFERENCES}

1. Murray CJ, Vos T, Lozano R, Naghavi M, Flaxman AD, Michaud C, Ezzati M, Shibuya K, Salomon JA, Abdalla S, Aboyans V, Abraham J, Ackerman I, Aggarwal R, Ahn SY, Ali 
MK, Alvarado M, Anderson HR, Anderson LM, Andrews KG, Atkinson C, Baddour LM, Bahalim AN, Barker-Collo S, Barrero LH, Bartels DH, Basanez MG, Baxter A, Bell ML, Benjamin EJ, Bennett D, Bernabe E, Bhalla K, Bhandari B, Bikbov B, Bin Abdulhak A, Birbeck G, Black JA, Blencowe H, Blore JD, Blyth F, Bolliger I, Bonaventure A, Boufous S, Bourne R, Boussinesq M, Braithwaite T, Brayne C, Bridgett L, Brooker S, Brooks P, Brugha TS, Bryan-Hancock C, Bucello C, Buchbinder R, Buckle G, Budke CM, Burch M, Burney P, Burstein R, Calabria B, Campbell B, Canter CE, Carabin H, Carapetis J, Carmona L, Cella C, Charlson F, Chen H, Cheng AT, Chou D, Chugh SS, Coffeng LE, Colan SD, Colquhoun S, Colson KE, Condon J, Connor MD, Cooper LT, Corriere M, Cortinovis M, de Vaccaro KC, Couser W, Cowie BC, Criqui MH, Cross M, Dabhadkar KC, Dahiya M, Dahodwala N, Damsere-Derry J, Danaei G, Davis A, De Leo D, Degenhardt L, Dellavalle R, Delossantos A, Denenberg J, Derrett S, Des Jarlais DC, Dharmaratne SD, Dherani M, Diaz-Torne C, Dolk H, Dorsey ER, Driscoll T, Duber H, Ebel B, Edmond K, Elbaz A, Ali SE, Erskine H, Erwin PJ, Espindola P, Ewoigbokhan SE, Farzadfar F, Feigin V, Felson DT, Ferrari A, Ferri CP, Fevre EM, Finucane MM, Flaxman S, Flood L, Foreman $\mathrm{K}$, Forouzanfar MH, Fowkes FG, Fransen M, Freeman MK, Gabbe BJ, Gabriel SE, Gakidou E, Ganatra HA, Garcia B, Gaspari F, Gillum RF, Gmel G, Gonzalez-Medina D, Gosselin R, Grainger R, Grant B, Groeger J, Guillemin F, Gunnell D, Gupta R, Haagsma J, Hagan H, Halasa YA, Hall W, Haring D, Haro JM, Harrison JE, Havmoeller R, Hay RJ, Higashi H, Hill C, Hoen B, Hoffman H, Hotez PJ, Hoy D, Huang JJ, Ibeanusi SE, Jacobsen KH, James SL, Jarvis D, Jasrasaria R, Jayaraman S, Johns N, Jonas JB, Karthikeyan G, Kassebaum N, Kawakami N, Keren A, Khoo JP, King CH, Knowlton LM, Kobusingye O, Koranteng A, Krishnamurthi R, Laden F, Lalloo R, Laslett LL, Lathlean T, Leasher JL, Lee YY, Leigh J, Levinson D, Lim SS, Limb E, Lin JK, Lipnick M, Lipshultz SE, Liu W, Loane M, Ohno SL, Lyons R, Mabweijano J, MacIntyre MF, Malekzadeh R, Mallinger L, Manivannan S, Marcenes W, March L, Margolis DJ, Marks GB, Marks R, Matsumori A, Matzopoulos R, Mayosi BM, McAnulty JH, McDermott MM, McGill N, McGrath J, Medina-Mora ME, Meltzer M, Mensah GA, Merriman TR, Meyer AC, Miglioli V, Miller M, Miller TR, Mitchell PB, Mock C, Mocumbi AO, Moffitt TE, Mokdad AA, Monasta L, Montico M, Moradi-Lakeh M, Moran A, Morawska L, Mori R, Murdoch ME, Mwaniki MK, Naidoo K, Nair MN, Naldi L, Narayan KM, Nelson PK, Nelson RG, Nevitt MC, Newton CR, Nolte S, Norman P, Norman R, O'Donnell M, O'Hanlon S, Olives C, Omer SB, Ortblad K, Osborne R, Ozgediz D, Page A, Pahari B, Pandian JD, Rivero AP, Patten SB, Pearce N, Padilla RP, Perez-Ruiz F, Perico N, Pesudovs K, Phillips D, Phillips MR, Pierce K, Pion S, Polanczyk GV, Polinder S, Pope CA, 3rd, Popova S, Porrini E, Pourmalek F, Prince M, Pullan RL, Ramaiah KD, Ranganathan D, Razavi H, Regan M, Rehm JT, Rein DB, Remuzzi G, Richardson K, Rivara FP, Roberts T, Robinson C, De Leon FR, Ronfani L, Room R, Rosenfeld LC, Rushton L, Sacco RL, Saha S, Sampson U, Sanchez-Riera L, Sanman E, Schwebel DC, Scott JG, Segui-Gomez M, Shahraz S, Shepard DS, Shin H, Shivakoti R, Singh D, Singh GM, Singh JA, Singleton J, Sleet DA, Sliwa K, Smith E, Smith JL, Stapelberg NJ, Steer A, Steiner T, Stolk WA, Stovner LJ, Sudfeld C, Syed S, Tamburlini G, Tavakkoli M, Taylor HR, Taylor JA, Taylor WJ, Thomas B, Thomson WM, Thurston GD, Tleyjeh IM, Tonelli M, Towbin JA, Truelsen T, Tsilimbaris MK, Ubeda C, Undurraga EA, van der Werf MJ, van Os J, Vavilala MS, Venketasubramanian N,
Wang M, Wang W, Watt K, Weatherall DJ, Weinstock MA, Weintraub R, Weisskopf MG, Weissman MM, White RA, Whiteford H, Wiebe N, Wiersma ST, Wilkinson JD, Williams HC, Williams SR, Witt E, Wolfe F, Woolf AD, Wulf S, Yeh PH, Zaidi AK, Zheng ZJ, Zonies D, Lopez AD, AlMazroa MA and Memish ZA. Disability-adjusted life years (DALYs) for 291 diseases and injuries in 21 regions, 1990-2010: A systematic analysis for the Global Burden of Disease Study 2010. Lancet. 2012; 380:2197-223.

2. Duval X, Delahaye F, Alla F, Tattevin P, Obadia JF, Le Moing V, Doco-Lecompte T, Celard M, Poyart C, Strady C, Chirouze C, Bes M, Cambau E, Iung B, Selton-Suty C, Hoen B, Group AS. Temporal trends in infective endocarditis in the context of prophylaxis guideline modifications: Three successive population-based surveys. J Am Coll Cardiol 2012; 59:19681976.

3. Correa de Sa DD, Tleyjeh IM, Anavekar NS, Schultz JC, Thomas JM, Lahr BD, Bachuwar A, Pazdernik M, Steckelberg JM, Wilson WR, Baddour LM. Epidemiological trends of infective endocarditis: A population-based study in Olmsted County, Minnesota. Mayo Clin Proc 2010; 85:422-426.

4. Federspiel JJ, Stearns SC, Peppercorn AF, Chu VH, Fowler VG. Jr. Increasing US rates of endocarditis with Staphylococcus aureus: 1999-2008. Arch Intern Med 2012; 172:363-365.

5. Thuny F, Grisoli D, Cautela J, Riberi A, Raoult D, Habib G. Infective endocarditis: Prevention, diagnosis, and management. Can J Cardiol 2014; 30:1046-1057.

6. Marelli AJ, Mackie AS, Ionescu-Ittu R, Rahme E, Pilote L. Congenital heart disease in the general population: changing prevalence and age distribution. Circulation 2007; 115:163-172.

7. Khairy P, Ionescu-Ittu R, Mackie AS, Abrahamowicz M, Pilote L, Marelli AJ. Changing mortality in congenital heart disease. J Am Coll Cardiol 2010; 56:1149-1157.

8. Habib G, Hoen B, Tornos P, Thuny F, Prendergast B, Vilacosta I, Moreillon P, de Jesus Antunes M, Thilen U, Lekakis J, Lengyel M, Muller L, Naber CK, Nihoyannopoulos P, Moritz A, Zamorano JL, Guidelines ESCCfP. Guidelines on the prevention, diagnosis, and treatment of infective endocarditis (new version 2009): the Task Force on the Prevention, Diagnosis, and Treatment of Infective Endocarditis of the European Society of Cardiology (ESC). Endorsed by the European Society of Clinical Microbiology and Infectious Diseases (ESCMID) and the International Society of Chemotherapy (ISC) for Infection and Cancer. Eur Heart J 2009; 30:2369-2413.

9. van der Meer JT, Thompson J, Valkenburg HA, Michel MF. Epidemiology of bacterial endocarditis in The Netherlands. II. Antecedent procedures and use of prophylaxis. Arch Intern Med 1992; 152:1869-1873.

10. Niwa K, Nakazawa M, Tateno S, Yoshinaga M, Terai M. Infective endocarditis in congenital heart disease: Japanese national collaboration study. Heart 2005; 91:795-800.

11. Li W, Somerville J. Infective endocarditis in the grown-up congenital heart $(\mathrm{GUCH})$ population. Eur Heart J 1998; 19:166173.

12. Wilson W, Taubert KA, Gewitz M, Lockhart PB, Baddour LM, Levison M, Bolger A, Cabell CH, Takahashi M, Baltimore RS, Newburger JW, Strom BL, Tani LY, Gerber M, Bonow RO, Pallasch T, Shulman ST, Rowley AH, Burns JC, Ferrieri P, Gardner T, Goff D, Durack DT, American Heart Association Rheumatic Fever E, Kawasaki Disease C, American Heart Association Council on Cardiovascular Disease in the $\mathrm{Y}$, American Heart Association Council on Clinical C, American Heart Association Council on Cardiovascular S, Anesthesia, Quality of C and Outcomes Research Interdisciplinary Working G. Prevention 
of infective endocarditis: Guidelines from the American Heart Association: a guideline from the American Heart Association Rheumatic Fever, Endocarditis, and Kawasaki Disease Committee, Council on Cardiovascular Disease in the Young, and the Council on Clinical Cardiology, Council on Cardiovascular Surgery and Anesthesia, and the Quality of Care and Outcomes Research Interdisciplinary Working Group. Circulation 2007; 116: 1736-1754.

13. Baltimore RS, Gewitz M, Baddour LM, Beerman LB, Jackson MA, Lockhart PB, Pahl E, Schutze GE, Shulman ST, Willoughby R. Jr.,American Heart Association Rheumatic Fever E, Kawasaki Disease Committee of the Council on Cardiovascular Disease in the $\mathrm{Y}$, the Council on $\mathrm{C}$ and Stroke N. Infective endocarditis in childhood: 2015 update: A scientific statement from the American Heart Association. Circulation 2015; 132: 1487-1515.

14. van der Linde D, Konings EE, Slager MA, Witsenburg M, Helbing WA, Takkenberg JJ, Roos-Hesselink JW. Birth prevalence of congenital heart disease worldwide: A systematic review and meta-analysis. J Am Coll Cardiol 2011; 58:2241-7.

15. Warnes CA, Williams RG, Bashore TM, Child JS, Connolly HM, Dearani JA, del Nido P, Fasules JW, Graham TP, Jr., Hijazi ZM, Hunt SA, King ME, Landzberg MJ, Miner PD, Radford MJ, Walsh EP, Webb GD, Smith SC, Jr., Jacobs AK, Adams CD, Anderson JL, Antman EM, Buller CE, Creager MA, Ettinger SM, Halperin JL, Hunt SA, Krumholz HM, Kushner FG, Lytle BW, Nishimura RA, Page RL, Riegel B, Tarkington LG, Yancy CW, American College of C, American Heart Association Task Force on Practice G, American Society of E, Heart Rhythm S, International Society for Adult Congenital Heart D, Society for Cardiovascular a, Interventions and Society of Thoracic S. ACC/AHA 2008 guidelines for the management of adults with congenital heart disease: A report of the American College of Cardiology/American Heart Association Task Force on Practice Guidelines (Writing Committee to Develop Guidelines on the Management of Adults With Congenital Heart Disease). Developed in Collaboration With the American Society of Echocardiography, Heart Rhythm Society, International Society for Adult Congenital Heart Disease, Society for Cardiovascular Angiography and Interventions, and Society of Thoracic Surgeons. J Am Coll Cardiol 2008; 52:e143-e263.

16. Mas JL, Derumeaux G, Amarenco P, Arquizan C, Aubry P, Barthelet M, Bertrand B, Brochet E, Cabanes L, Donal E, Dubois-Rande JL, Durand-Zaleski I, Ernande L, Finet G, Fraisse A, Giroud M, Guerin P, Habib G, Juliard JM, Leys D, Lievre M, Lusson JR, Marcon F, Michel P, Moulin T, Mounier-Vehier F, Pierard L, Piot C, Rey C, Rodier G, Roudaut R, Schleich JM, Teiger E, Turc G, Vuillier F, Weimar C, Woimant F, Chatellier $\mathrm{G}$, and Investigators $\mathrm{C}$. close: Closure of patent foramen ovale, oral anticoagulants or antiplatelet therapy to prevent stroke recurrence: Study design. Int J Stroke 2016.

17. Leong MC, Uebing A, Gatzoulis MA. Percutaneous patent foramen ovale occlusion: Current evidence and evolving clinical practice. Int J Cardiol 2013; 169:238-243.

18. Chessa M, Carminati M, Butera G, Bini RM, Drago M, Rosti L, Giamberti A, Pome G, Bossone E, Frigiola A. Early and late complications associated with transcatheter occlusion of secundum atrial septal defect. J Am Coll Cardiol 2002; 39:10611065.

19. Du ZD, Hijazi ZM, Kleinman CS, Silverman NH, Larntz K, Amplatzer I. Comparison between transcatheter and surgical closure of secundum atrial septal defect in children and adults: Results of a multicenter nonrandomized trial. J Am Coll Cardiol 2002; 39:1836-1844.
20. Masura J, Gavora P, Podnar T. Long-term outcome of transcatheter secundum-type atrial septal defect closure using Amplatzer septal occluders. J Am Coll Cardiol 2005; 45:505-507.

21. Majunke N, Bialkowski J, Wilson N, Szkutnik M, Kusa J, Baranowski A, Heinisch C, Ostermayer S, Wunderlich N, Sievert H. Closure of atrial septal defect with the Amplatzer septal occluder in adults. Am J Cardiol 2009; 103:550-554.

22. Haas NA, Soetemann DB, Ates I, Baspinar O, Ditkivskyy I, Duke C, Godart F, Lorber A, Oliveira E, Onorato E, Pac F, Promphan W, Riede FT, Roymanee S, Sabiniewicz R, Shebani SO, Sievert H, Tin D, Happel CM. Closure of secundum atrial septal defects by using the occlutech occluder devices in more than 1300 patients: The IRFACODE project: A retrospective case series. Catheter Cardiovasc Interv 2016.

23. O’Byrne ML, Glatz AC, Sunderji S, Mathew AE, Goldberg DJ, Dori Y, Rome JJ, Gillespie MJ. Prevalence of deficient retroaortic rim and its effects on outcomes in device closure of atrial septal defects. Pediatr Cardiol 2014; 35:1181-1190.

24. Kutty S, Hazeem AA, Brown K, Danford CJ, Worley SE, Delaney JW, Danford DA, Latson LA. Long-term (5- to 20year) outcomes after transcatheter or surgical treatment of hemodynamically significant isolated secundum atrial septal defect. Am J Cardiol 2012; 109:1348-1352.

25. Butera G, Biondi-Zoccai G, Sangiorgi G, Abella R, Giamberti A, Bussadori C, Sheiban I, Saliba Z, Santoro T, Pelissero G, Carminati M, Frigiola A. Percutaneous versus surgical closure of secundum atrial septal defects: A systematic review and meta-analysis of currently available clinical evidence. EuroIntervention 2011; 7:377-385.

26. Delaney JW, Li JS, Rhodes JF. Major complications associated with transcatheter atrial septal occluder implantation: A review of the medical literature and the manufacturer and user facility device experience (MAUDE) database. Congenit Heart Dis 2007; 2:256-264.

27. DiBardino DJ, McElhinney DB, Kaza AK, Mayer JE Jr. Analysis of the US Food and Drug Administration Manufacturer and User Facility Device Experience database for adverse events involving Amplatzer septal occluder devices and comparison with the Society of Thoracic Surgery congenital cardiac surgery database. J Thorac Cardiovasc Surg 2009; 137: 1334-1341.

28. Sievert H, Babic UU, Hausdorf G, Schneider M, Hopp HW, Pfeiffer D, Pfisterer M, Friedli B, Urban P. Transcatheter closure of atrial septal defect and patent foramen ovale with ASDOS device (a multi-institutional European trial). Am J Cardiol 1998; 82:1405-1413.

29. Bullock AM, Menahem S, Wilkinson JL. Infective endocarditis on an occluder closing an atrial septal defect. Cardiol oung 1999; 9:65-67.

30. Goldstein JA, Beardslee MA, Xu H, Sundt TM, Lasala JM. Infective endocarditis resulting from CardioSEAL closure of a patent foramen ovale. Catheter Cardiovasc Interv 2002; 55:217220; discussion 221 .

31. Calachanis M, Carrieri L, Grimaldi R, Veglio F, Orzan F. Infective endocarditis after transcatheter closure of a patent foramen ovale. Catheter Cardiovasc Interv 2004; 63:351-354.

32. Balasundaram RP, Anandaraja S, Juneja R, Choudhary SK. Infective endocarditis following implantation of amplatzer atrial septal occluder. Indian Heart J 2005; 57:167-169.

33. Divchev D, Podewski EK, Mengel M, Meyer GP, Drexler H, Schaefer A. Inflammatory, abscess-forming foreign body reaction mimics a thrombus formation on an atrial septal defect closure device: A commented case report. Eur J Echocardiogr 2007; 8:298-302. 
34. Slesnick TC, Nugent AW, Fraser CD Jr., Cannon BC. Images in ardiovascular edicine. Incomplete endothelialization and late development of acute bacterial endocarditis after implantation of an Amplatzer septal occluder device. Circulation 2008; 117: e326-e327.

35. Zahr F, Katz WE, Toyoda Y, Anderson WD. Late bacterial endocarditis of an amplatzer atrial septal defect occluder device. Am J Cardiol 2010; 105:279-280.

36. Doguet F, Leguillou V, Godin M. Infected amplatzer device. J Card Surg 2011; 26:75.

37. Verma SK, Tobis JM. Explantation of patent foramen ovale closure devices: A multicenter survey. JACC Cardiovasc Interv 2011; 4:579-585.

38. Walpot J, Amsel B, Rodrigus I, Pasteuning WH, Koeman J, Hokken R. Late infective endocarditis of an atrial septal occluder device presenting as a cystic mass. Echocardiography 2011; 28:E131-E133.

39. Sadiq M, Kazmi T, Rehman AU, Latif F, Hyder N, Qureshi SA. Device closure of atrial septal defect: Medium-term outcome with special reference to complications. Cardiol Young 2012; 22:71-78.

40. Aruni B, Sharifian A, Eryazici P, Herrera CJ. Late bacterial endocarditis of an Amplatzer atrial septal device. Indian Heart J 2013; 65:4501.

41. Krantz SB, Lawton JS. Subacute endocarditis of an atrial septal closure device in a patient with a patent foramen ovale. Ann Thoracic Surg 2014; 98:1821-1823.

42. Iezzi F, Cini R, Sordini P, Pristipino C. Bacterial endocarditis on transcatheter Amplatzer device. J Case Rep Practice 2014; 2 : 4-5.

43. Jha NK, Kiraly L, Murala JS, Tamas C, Talo H, El Badaoui H, Tofeig M, Mendonca M, Sajwani S, Thomas MA, Al Doory SA, Khan MD. Late endocarditis of Amplatzer atrial septal occluder device in a child. World J Cardiol 2015; 7:703-706.
44. Kim DJ, Shim CY, You SC, Lee SH, Hong GR. Late bacterial endocarditis and abscess formation after implantation of an amplatzer septal occluder device. Circulation 2015; 131:e536e538.

45. Thibodeau-Jarry N, Ibrahim R, Ducharme A, Sia YT. Late infection of an atrial septal defect closure device: A possible complication. Can J Cardiol 2015; 31:1204 e9-e11.

46. Bialkowski J, Pawlak S, Banaszak P. Incomplete endothelialisation of an Amplatzer Septal Occluder device followed by meningitis and late acute bacterial endocarditis. Cardiol Young 2016; 26:808-810.

47. Nguyen AK, Palafox BA, Starr JP, Gates RN, Berdjis F. Endocarditis and incomplete endothelialization 12 years after amplatzer septal occluder deployment. Tex Heart Inst J 2016; 43:227-231.

48. Bressieux-Degueldre S, Sekarski N, Di Bernardo S. Fungal endocarditis after hybrid periventricular closure of muscular ventricular septal defect by Amplatzer occluder in a child. Circulation 2015; 131:e339-e340.

49. Tuncer M, Ekim H, Gunes Y, Guntekin U. Atrial septal defect presenting with Brucella endocarditis. Circ J 2008; 72:20962097.

50. Stoica L, Tinica G, Gradinariu G, Butcovan D, Macovei L. Patch abscess after a closure of an atrial septal defect. Eur Heart J Cardiovasc Imaging 2014; 15:179.

51. Lock JE, Rome JJ, Davis R, Van Praagh S, Perry SB, Van Praagh R, Keane JF. Transcatheter closure of atrial septal defects. Experimental studies. Circulation 1989; 79:1091-1099.

52. Naik RJ, Patel NR, Wang M, Shah NC. Infective endocarditis prophylaxis: Current practice trend among paediatric cardiologists: Are we following the 2007 guidelines? Cardiol Young 2015:1-7.

53. Bialkowski J, Pawlak S, Banaszak P. Incomplete endothelialisation of an Amplatzer Septal Occluder device followed by meningitis and late acute bacterial endocarditis. Cardiol oung 2015; 1-3. 